\title{
Tourist Accommodation Facilities in the major Tourist Areas of Nepal
}

\author{
Ram Chandra Sedai \\ sedairam@yahoo.com
}

\begin{abstract}
Accommodation sector constitutes one of the major components of tourism industry globally out of its popular 4 ' $A$ ' i.e. Attractions, Accessibility, Accommodation and Ancillary facilities. Accommodation sector, which is also considered as one of the major sub-sectors of tourism industry globally, has a huge potential to generate employment and income through the addition of values within its multiple layers of chains. Tourism accommodation is also one of the determinants of tourist choice for their destination.

The overall objective of this article is to analyze and interpret the outcomes of the research study on tourist accommodation inventory carried out by NTB in June 2010, focusing on the capacity of tourism accommodation enterprises available in the major tourist areas of Nepal. More specifically, the article analyzes and interprets the findings of the research outcomes in the following aspects:
\end{abstract}

Status of accommodation facilities by number of tourist enterprises, tourist rooms and tourist beds.

Status of accommodation facilities by type and standard.

Status of accommodation facilities by the status of registration.

Keywords: Accomodation; Atractions; Accessibility; Ancillary Facilities; Tourism Rooms and Standards

\section{Introduction}

The tourism industry in Nepal has been flourishing and growing primarily due to its incomparable tourist attractions despite having very basic and even inadequate accommodation, accessibility and other ancillary facilities and services. Endowed with an unparalleled combination of natural, cultural and historical attractions, Nepal has been one of the popular tourist destinations in the global tourist market and has been offering unique tourist activities like mountaineering, adventure and soft trekking and cultural tours, jungle safari, wilderness trek and other various sports and adventure tourist activities. 
Tourism in Nepal started with the camping accommodation since the very beginning of the 1950s when Maurice Herzog and his team scaled Mt Annapurna on June 3, 1950 and Tenzing N Sherpa and Edmund Hillary first ascended Mt Everest in 1953. The formal growth of accommodation facilities in Nepal started with the establishment of 'Royal Hotel' by a Russian national, Mr Boris Lissanevitch, in February 1955 (Satyal, 2004). However, the planned development of tourism in Nepal started after 1956 with the starting of the first five-year plan (1956-1961 AD) and subsequent establishment of Tourist Development Board in 1957 under the Department of Industry (Dol).

Within the jurisdiction of Ministry of Tourism and Civil Aviation (MoTCA), Tourism Industry Division (TID) has been designated to oversee all activities including registering, renewing, maintaining the inventory and monitoring the activities relevant to tourism-related enterprises including accommodation enterprises in Nepal. Besides expanding and upgrading the accommodation facilities and services in the existing tourist destinations, the Government of Nepal is consistently working with other stakeholders including the Nepal Tourism Board (NTB), private sectors, local government bodies, NGOs and development partners for the development and promotion of new tourism destinations for which the availability of reliable and consistent accommodation facilities and services become always a prerequisite. The need for the expansion and upgrading of these facilities are more pertinent in the special context when the Government of Nepal and the entire tourism industry has launched 'Nepal Tourism Year - NTY $2011^{\prime}$ as a national campaign targeting one million tourists in the year 2011 as one of its aims.

As of 2009, a total of 736 hotels of various standards and categories have been registered at TID/MoTCA offering 14,272 tourist rooms and 28,485 tourist beds. The accommodation facilities in Kathmandu alone comprise 422 hotels, 8,813 tourist rooms and 17,646 tourist beds, or $61.94 \%$ of the total capacity (NTS/ MOTCA, 2009). However, it has been widely realized that the actual capacity of accommodation facilities in Nepal is larger than that of formal records maintained at TID/MoTCA. By considering the possible data gap in the accommodation sector and by also intending to establish a destination-level database on accommodation sector, Research Planning and Monitoring Department of NTB designed and carried out a research study on tourist accommodation enterprises entitled, 'Inventory of formal accommodation facilities in the major selected tourist areas of Nepal' from April to June 2010 by outsourcing the technical services of Centre for Environment and Sustainable Tourism Development Nepal (CEST Nepal). This research article aims to highlight the overall inventory scenario of accommodation facilities in Nepal primarily based on the findings of the accommodation research work carried out in June 2010. 


\section{Literature Review}

There is no universal system of classification and standard of accommodation facilities throughout the world. It varies with the location, types of tourist products. ITRS 2008 provides a comprehensive methodological framework for collection and compilation of tourism statistics in all countries irrespective of the level of development of their statistical systems. UNWTO/ITRS (2008) has simply classified the accommodation into two basic forms such as commercial (market/paid) or non-commercial (non-market), that is, as a service provided by family, friends or relatives, without charge, or on own account (owner-occupied vacation homes) (UNWTO/UNDP ITRS, 2008).

In the context of Nepalese tourism, Tourism Act 2035 BS (1978 AD) and Hotel, Lodge, Restaurant, Bar and Tour Guide Regulation 2038 BS (1981 AD), provide legal basis for the establishment and operation of all forms of tourism-related enterprises including accommodation enterprises in Nepal. Within the framework of Tourism Act 1978 and Regulation 1981, Internal Working Procedure 2064 provides procedure for the establishment, classification, operation, renewal and monitoring of all forms of tourist accommodation enterprises. Furthermore, the government's notification published in the Nepal Gazette dated Ashadh 4, 2055, provides basic criteria to be fulfilled for the registration of tourist enterprises under the category of tourist resorts and star hotels. The Homestay Operating Procedure 2067 (2010) prepared as per the aspiration of Tourism Policy 2009, provides bases for the registration and operation of homestay on an individual as well as community basis. National Parks and Wildlife Conservation Act 1973, Buffer Zone Management Regulation 1996, Conservation Area Management Regulation 1996 and Conservation Area Government Management Regulation 2057 BS, provide bases for the operation of any services including establishment of accommodation enterprises inside the protected areas (PAs).

\section{Procedure for the Registration of Tourist Accommodation Enterprises}

Under the provisions made in the Regulation 1981, Internal Working Procedure 2064, Government's notification published on Ashadh 4, 2055, and Homestay Operating Procedure 2010, following procedure should be followed to register any accommodation enterprise as tourist standard accommodation enterprise:

i. Any potential entrepreneur willing to register a tourist standard accommodation should first resister an accommodation enterprise either at the Company Registration Office or at the Department of Industry (Dol) or the Cottage and Small Industry Development Board (CSIDB) and should get a registration certificate. 
ii. Then the entrepreneur should submit an application at the Tourism Industry Division (TID), Bhrikutimandap, Kathmandu or respective tourism offices in Kakadbhitta, Janakpur, Birgunj, Pokhara, Bhairahawa and Nepalgunj, in a prescribed format and by enclosing prescribed documents including a recommendation letter from either the Department of Industry (Dol) or the Cottage and Small Industry Development Board (CSIDB).

iii. After submitting a field verification report by the prescribed officer, the enterprise can be registered as a tourist standard accommodation enterprise.

iv. For the case of homestay, both the individual homestay as well as community homestay can be registered at the TID or tourism offices. For community homestay, an agreement paper signed by at least five homestay members operating on a community basis should be enclosed with the application. Whereas for the individual homestay, a recommendation letter from the respective VDC or municipality along with the land ownership certificate should be enclosed with the application.

v. Accommodation enterprises within the territory of protected areas can be run by getting permission from and registered at the respective PAs. However, such enterprise should be registered at the TID if they are to be run as tourist standard hotels.

vi. All categories of tourist accommodation enterprises are entitled to submit the progress report to the TID and respective tourism offices on an annual basis and should renew the enterprise every five years.

\section{Classification/Standardization of Tourist Accommodation Enterprises}

Based on the provisions set in the existing Act, Regulation, Directives and Procedures, any tourist accommodation enterprise (hotels/lodges) can be registered under the categories of

(i) Tourist standard hotel (TSH) or tourist class hotel (TCH),

(ii) Lodge,

(iii) Resorts (jungle resort, mountain resort, tourist resort and safari camp),

(iv) Star hotels (1 star to 5 star hotels) and

(v) Homestays. Both physical criteria (Table 1) and subjective criteria (quality and hospitality level etc.) are taken into consideration while classifying the enterprises. 


\begin{tabular}{|c|c|c|c|c|c|c|c|c|c|c|}
\hline \multirow{2}{*}{ Criteria } & \multicolumn{9}{|c|}{ Classification } \\
\cline { 2 - 10 } & \multicolumn{5}{|c|}{ Non-star category } & \multicolumn{5}{c|}{ Star category } \\
\cline { 2 - 9 } & Homestay & TSH & Lodge & Resorts & 1 star & 2 star & 3 star & 4 star & 5 star \\
\hline $\begin{array}{c}\text { Physical } \\
\text { location }\end{array}$ & $\begin{array}{c}\text { Homely } \\
\text { environment }\end{array}$ & $\begin{array}{c}\text { Any } \\
\text { suitable } \\
\text { place }\end{array}$ & $\begin{array}{c}\text { Any } \\
\text { suitable } \\
\text { place }\end{array}$ & $\begin{array}{c}\text { Far from } \\
\text { dense } \\
\text { settlement }\end{array}$ & \multicolumn{4}{|c|}{$\begin{array}{c}\text { Any suitable place with good views, } \\
\text { adequate spac e, drainage facilities etc. }\end{array}$} \\
\hline $\begin{array}{c}\text { Room size } \\
\text { (Minimum) }\end{array}$ & $1^{*}$ & 10 & 5 & Flexible & 15 & 20 & 30 & 50 & 70 \\
\hline $\begin{array}{c}\text { Bed size } \\
\text { (Minimum) }\end{array}$ & At least 2 & 1 & $\begin{array}{c}25 \% \\
\text { room** }\end{array}$ & $\begin{array}{c}25 \% \\
\text { room** }\end{array}$ & 2 to 3 & $\begin{array}{c}25 \% \\
\text { room } \\
* * *\end{array}$ & All & All & All & All \\
\hline $\begin{array}{c}\text { Bathroom } \\
\text { and Toilet } \\
\text { (Minimum) }\end{array}$ & 1 & & & & & & & \\
\hline
\end{tabular}

*= Maximum room per homestay is 4; **= Additionally, there must be 1 toilet and bathroom for every 4 rooms; ${ }^{* * *}=$ Also equipped with fixture and amenities. Additional restroom, separate for men and women, at the nearby areas of reception.

Table 1: Basic physical criteria set for the classification of tourism accommodations

\section{Brief trend of tourist accommodation enterprises development in Nepal}

The formal tourist accommodation development in Nepal started with the enactment of the five-year development plan in 1956. The first hotel, Royal Hotel was established by a Russian national with 40 rooms and 50 tourist beds, followed by the establishment of Hotel Snow View comprising 23 rooms and 38 tourist beds, making altogether 78 tourist beds by the year 1959 (Satyal, 2004). During the $2^{\text {nd }}$ five-year plan period (1962-66), tourism activities were also expanded to Pokhara and Lumbini and the total number of tourist beds reached 177 by the year 1964 (Satyal 2004).

More emphasis was given to the establishment of hotels of international standard in Kathmandu, Pokhara and Biratnagar during the $3^{\text {rd }}$ five-year plan period (1966-1970) along with the establishment of Hotel Association Nepal (HAN) in 1967. During the same period, Hotel Soaltee was established in 1965 and Hotel Annapurna in 1966. By the year 1965, the total number of beds reached 356 with 56 tourist beds outside Kathmandu ( 8 in Kakani, 4 in Nagarkot, 30 in Pokhara, 12 in Lumbini, and 2 in Daman) (Satyal 2004). By the end of 1970, the total number of beds reached 1,500 (Satyal 2004).

During the $4^{\text {th }}$ five-year plan (1970-1975) period, the accommodation enterprises expanded in both numbers and geographical coverage with the formation of the first Tourism Master Plan in 1972 and the establishment of Hotel Management \& Tourism Training Centre (HMTTC) in 1972. More adventure, ecotourism and 
safari-based tourist accommodations were also established in Sagarmatha National Park (SNP), Chitwan National Park (CNP), Langtang National Park (LNP) and other protected areas (PAs) after the enactment of the National Parks and Wildlife Conservation Act 1973.

The need for the classification of hotel enterprises was taken into consideration during the 1970s. A total of 15 classified (star) hotels comprising 461 room and 1,069 tourist beds were established in Kathmandu by 1971. Among them, Hotel Soaltee Oberoi was the only five star hotel whereas Annapurna was the only four star hotel in Nepal (Satyal 2004). Likewise, there were six tourist hotels with 74 room and 1,444 beds outside Kathmandu including one in Biratnagar (Birat Hotel), two hotels in Pokhara (Fish Tail Hotel and Snow View Hotel), one in Chitwan (Tiger Tops), one in Nagarkot (Mt Everest Lodge) and one in Syangboche/Everest (Everest View Hotel). The more planned and systematic development of tourist accommodation enterprises received a momentum after the establishment of Ministry of Tourism on February 23, 1977 and subsequent enactment of Tourism Act 1978.

As of 1997, the total hotel number was 706 with 14,214 tourist rooms and 27,612 tourist beds. The number of hotels declined slightly almost throughout the $9^{\text {th }}$ and $10^{\text {th }}$ five-year plan periods due to a decade long political conflict in the country and again crossed the 1997 level by the end of 2009 as a result of the signing of the Comprehensive Peace Accord in 2006.

\begin{tabular}{|c|c|c|c|c|c|c|c|c|c|}
\hline \multirow{2}{*}{ 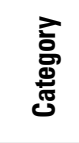 } & \multicolumn{3}{|c|}{ Kathmandu Valley } & \multicolumn{3}{|c|}{ Out of Kathmandu } & \multicolumn{3}{|c|}{ Grand Total } \\
\hline & $\begin{array}{l}\text { No. of } \\
\text { Hotel }\end{array}$ & $\begin{array}{l}\text { No. of } \\
\text { Room }\end{array}$ & $\begin{array}{c}\text { No. of } \\
\text { Bed }\end{array}$ & $\begin{array}{l}\text { No. of } \\
\text { Hotel }\end{array}$ & $\begin{array}{l}\text { No. of } \\
\text { Room }\end{array}$ & $\begin{array}{c}\text { No. of } \\
\text { Bed }\end{array}$ & $\begin{array}{l}\text { No. of } \\
\text { Hotel }\end{array}$ & $\begin{array}{l}\text { No. of } \\
\text { Room }\end{array}$ & $\begin{array}{c}\text { No. of } \\
\text { Bed }\end{array}$ \\
\hline 5 Star & 8 & 1539 & 2897 & 2 & 283 & 566 & 10 & 1822 & 3463 \\
\hline 4 Star & 2 & 190 & 362 & 0 & 20 & 0 & 2 & 210 & 362 \\
\hline 3 Star & 11 & 372 & 774 & 6 & 265 & 509 & 17 & 637 & 1283 \\
\hline 2 Star & 27 & 1138 & 2263 & 4 & 128 & 238 & 31 & 1266 & 2501 \\
\hline 1 Star & 26 & 564 & 1374 & 11 & 174 & 386 & 37 & 738 & 1760 \\
\hline TSH & 348 & 5010 & 9974 & 291 & 4609 & 9140 & 639 & 9619 & 19114 \\
\hline & 422 & 8813 & 17646 & 314 & 5459 & 10839 & 736 & 14272 & 28485 \\
\hline
\end{tabular}

Table-2: Hotel accommodation as of 2009 (NTS 2009)

Source: NTS/MoTCA, 2009

\section{Methodology of the Research Work}

\section{Selection of tourist sites for the inventory work:}

Following 15 major and five minor areas which have been already recognized as popular tourist destinations/sites or lie en-route to the popular destinations 
have been selected for the research work. Tourist areas which still need to rely on camping accommodation for the lodging and food facilities on a mandatory basis have been excluded in the research.

\begin{tabular}{|c|c|c|}
\hline SN & Destinations/Sites & Major places covered \\
\hline 1 & Kathmandu and Lalitpur & Kathmandu and Lalitpur urban areas, Godavari, Hattiban, Gokarna \\
\hline 2 & $\begin{array}{l}\text { Bhaktapur, Nagarkot, } \\
\text { Dhulikhel }\end{array}$ & Nagarkot, Bhaktapur, Dhulikhel, Panauti, Namobuddha \\
\hline 3 & Pokhara Valley & Pokhara city and nearest surroundings \\
\hline 4 & Annapurna Region & $\begin{array}{l}\text { Ghandruk route, Ghorepani route, ABC trek, Jomsom, } \\
\text { Lomangthang, Muktinath, Manang, Ghalegaun areas }\end{array}$ \\
\hline 5 & Chitwan Area & Chitwan NP and surroundings, Kurintar, Bharatpur, Nawalparasi \\
\hline 6 & Everest Region & Junbesi, Salleri, Lukla, Namche, Everest Base Camp \\
\hline 7 & $\begin{array}{l}\text { Rolwaling, Numbur, } \\
\text { Sailung }\end{array}$ & $\begin{array}{l}\text { Charikot, Rolwaling, Jiri, Shivalaya, Bhandar, Numbur, Sailung } \\
\text {-Lubughat (IP Trail) }\end{array}$ \\
\hline 8 & $\begin{array}{l}\text { Langtang, Helambu } \\
\text { Region }\end{array}$ & $\begin{array}{l}\text { Tamang Heritage Trail, Langtang/Kanjin trail, Goshaikunda trail, } \\
\text { Chisapani-Helambu region }\end{array}$ \\
\hline 9 & $\begin{array}{l}\text { Biratnagar, Jhapa, Ilam, } \\
\text { Dharan and Dhankuta }\end{array}$ & $\begin{array}{l}\text { Biratnagar, Itahari, Kakadbhitta, Damak, Ilam, Phikkal, Dharan, } \\
\text { Bhedetar, Dhankuta, Hile }\end{array}$ \\
\hline 10 & Kanchenjunga Region & Phungling, Suketar, Phungling-Ghunsa route \\
\hline 11 & $\begin{array}{l}\text { Hetauda, Birgunj, } \\
\text { Janakpur }\end{array}$ & Hetauda, Birgunj, Simara, Janakpur \\
\hline 12 & $\begin{array}{l}\text { Trishuli, Gorkha, } \\
\text { Bandipur, Besisahar }\end{array}$ & Trishuli, Manakamana, Gorkha, Bandipur, Damauli, Besisahar \\
\hline 13 & Lumbini, Palpa, Butwal & Tansen, Butwal, Bhairahawa, Sunauli, Siddharthanagar, Lumbini \\
\hline 14 & $\begin{array}{l}\text { Nepalgunj, Bardiya and } \\
\text { Surkhet }\end{array}$ & Nepalgunj, Gulariya, Thakurdwara, Surkhet \\
\hline 15 & $\begin{array}{l}\text { Dhangadhi and } \\
\text { Mahendranagar }\end{array}$ & Dhangadhi, Mahendranagar, Shuklaphanta \\
\hline 16 & $\begin{array}{l}\text { Other miscellaneous } \\
\text { areas }\end{array}$ & $\begin{array}{l}\text { Kodari Highway (Sindhupalchowk), Kakani, Daman, Khandbari, } \\
\text { Sirubari, Barapak }\end{array}$ \\
\hline
\end{tabular}

Table 3: Major tourism areas covered in the research work 2010

\section{Collection of primary and secondary data:}

Following methods were used to collect primary and secondary data:

\section{Collection of secondary data from the reliable sources}

Available reliable secondary data were gathered from the following relevant sources: 


\begin{tabular}{|c|c|c|c|}
\hline SN & Major source of data & $\begin{array}{l}\text { Responsible } \\
\text { Institutions }\end{array}$ & Major tourist sites covered \\
\hline 1 & \begin{tabular}{|l} 
Registered Tourism Related \\
Enterprises 2008
\end{tabular} & $\begin{array}{l}\text { Tourism Industry } \\
\text { Division/MoTCA }\end{array}$ & $\begin{array}{l}\text { All tourist accommodation enterprises } \\
\text { registered at TID/Kathmandu and all } \\
\text { tourism offices }\end{array}$ \\
\hline 2 & $\begin{array}{l}\text { Detailed list of tourist } \\
\text { enterprises maintained at } \\
\text { IT/Computer Section TID }\end{array}$ & $\begin{array}{l}\text { IT/Computer Section } \\
\text { TID/MoTCA }\end{array}$ & $\begin{array}{l}\text { All tourist accommodation enterprises } \\
\text { registered at TID/Kathmandu and all } \\
\text { tourism offices }\end{array}$ \\
\hline 3 & Hotel Directory 2008 & $\begin{array}{l}\text { Published by Hotel } \\
\text { Association Nepal, } \\
\text { HAN, } 2008\end{array}$ & $\begin{array}{l}\text { All star hotels, resorts and tourist } \\
\text { standard hotels affiliated to HAN till } \\
2008 .\end{array}$ \\
\hline 4 & $\begin{array}{l}\text { Letter written by Langtang } \\
\text { NP to NTB }\end{array}$ & Langtang NP & $\begin{array}{l}\text { All permitted/registered hotels inside } \\
\text { Langtang National Park }\end{array}$ \\
\hline 5 & $\begin{array}{l}\text { List of hotels, lodges and } \\
\text { homestays provided by } \\
\text { ACAP }\end{array}$ & $\begin{array}{l}\text { ACAP Head Office, } \\
\text { Pokhara and Unit } \\
\text { Conservation } \\
\text { Offices, Ghandruk } \\
\text { and Jomsom }\end{array}$ & $\begin{array}{l}\text { Lwang, Ghorepani, Ghandruk, } \\
\text { Jomsom, Upper Mustang, Manang, } \\
\text { Khudi, Ghalegaun, Sikles }\end{array}$ \\
\hline 6 & $\begin{array}{l}\text { ILO/EmPLED Tourism Report, } \\
2010\end{array}$ & $\begin{array}{l}\text { ILO/EmPLED, } \\
\text { Kathmandu }\end{array}$ & $\begin{array}{l}\text { Numbur-Cheese Circuit and } \\
\text { Indigenous Peoples Trail, Ramechhap }\end{array}$ \\
\hline 7 & $\begin{array}{l}\text { Experiencing Eco-Lodge } \\
\text { Trekking in the unspoilt } \\
\text { Gauri Shankar Area, } \\
\text { Brochure, } 2007\end{array}$ & $\begin{array}{l}\text { Eco-Himal, } \\
\text { Baluwatar, } \\
\text { Kathmandu, } 2007\end{array}$ & $\begin{array}{l}\text { Rolwaling areas - Dolangsa, Bigu, } \\
\text { Loting, Laduk, Orang, Simigaun areas } \\
\text { of Dolakha }\end{array}$ \\
\hline 8 & $\begin{array}{l}\text { Database provided by Ms } \\
\text { Dil Kumari Ghale, Barapak, } \\
\text { Gorkha }\end{array}$ & $\begin{array}{l}\text { Adventure Rural } \\
\text { Development } \\
\text { Programme, Nepal }\end{array}$ & Barapak homestay village, Gorkha \\
\hline 9 & $\begin{array}{l}\text { Database provided by Mr } \\
\text { Jum Bahadur Gurung, } \\
\text { Sirubari, Syangja }\end{array}$ & $\begin{array}{l}\text { Sirubari Tourism } \\
\text { Development } \\
\text { Committee }\end{array}$ & Sirubari tourism village, Syangja \\
\hline 10 & $\begin{array}{l}\text { Tourism Plan of } \\
\text { Manakamana, Betini and } \\
\text { Bakreshwori }\end{array}$ & $\begin{array}{l}\text { NTB/CEST Nepal } \\
2008\end{array}$ & Manakamana areas \\
\hline
\end{tabular}

Table 4: Sources of information and institutions for secondary data

Key stakeholders such as TID/MoTCA, RPMD/NTB, Department of National Parks and Wildlife Conservation (DNPWC), National Trust for Nature Conservation (NTNC), Hotel Association Nepal (HAN) and relevant tourism committees were consulted to ensure the conceptual clarity on the registration, operation and controlling process for tourist accommodation enterprises as well as to ensure the credibility of the data obtained from the respective institutions. 


\section{Field visit and accommodation enterprise survey:}

Detail field visits and accommodation enterprise survey was carried out in the above 10 research sites (Table 3 ).

i. The list of tourist accommodation enterprises obtained from the secondary sources (Table 4) was verified at the field by the researchers. The expansion or deduction in the tourist bed capacity was detected and corrected accordingly. Likewise, the hotels/lodges which were shut down in the real ground were marked and deleted from the inventory list.

ii. All newly established and/or additional tourist accommodation enterprises which were not listed in the TID/MoTCA inventory list but were offering accommodation services and facilities to the visitors were surveyed by using a standard format by the enumerators. Accommodation enterprises which were registered at the local authorities like VDCs, municipalities and PAs other than the TID/MoTCA were also surveyed by the enumerators during the research.

\begin{tabular}{|l|l|l|l|}
\hline SN & Research sites & $\begin{array}{c}\text { Major places covered for the } \\
\text { inventory during survey }\end{array}$ & Major features of the inventory \\
\hline 1 & $\begin{array}{l}\text { Rasuwa, Nuwakot, } \\
\text { Sindhupalchowk }\end{array}$ & $\begin{array}{l}\text { Tamang Heritage Trail, Langtang } \\
\text { and Helambu region }\end{array}$ & $\begin{array}{l}\text { Detail inventory of individual } \\
\text { hotels, field verification }\end{array}$ \\
\hline 2 & $\begin{array}{l}\text { Kathmandu and } \\
\text { Lalitpur }\end{array}$ & Kathmandu and Lalitpur & $\begin{array}{l}\text { Only verification of new hotels } \\
\text { and hotels which are shut down }\end{array}$ \\
\hline 3 & $\begin{array}{l}\text { Palpa, Rupandehi, } \\
\text { Kapilvastu }\end{array}$ & $\begin{array}{l}\text { Palpa, Lumbini, Nepalgunj, } \\
\text { Surkhet, Bardiya, Dhangadhi, } \\
\text { Mahendranagar }\end{array}$ & $\begin{array}{l}\text { Detail inventory of individual } \\
\text { hotels, field verification }\end{array}$ \\
\hline 4 & $\begin{array}{l}\text { Sunsari, Jhapa, } \\
\text { Morang, Ilam, } \\
\text { Dhankuta }\end{array}$ & $\begin{array}{l}\text { Biratnagar, Jhapa, llam, Dharan, } \\
\text { Dhankuta }\end{array}$ & $\begin{array}{l}\text { Detail inventory of individual } \\
\text { hotels, field verification }\end{array}$ \\
\hline 5 & $\begin{array}{l}\text { Dhading, Gorkha, } \\
\text { Tanahun, Lamjung }\end{array}$ & $\begin{array}{l}\text { Gorkha, Bandipur, Damauli, } \\
\text { Besisahar, Pokhara, Beni-Tatopani }\end{array}$ & $\begin{array}{l}\text { Detail inventory of individual } \\
\text { hotels, field verification }\end{array}$ \\
\hline 6 & $\begin{array}{l}\text { Chitwan, } \\
\text { Makawanpur, } \\
\text { Parsa, Dhanusha }\end{array}$ & $\begin{array}{l}\text { Chitwan, Hetauda, Birgunj and } \\
\text { Janakpur }\end{array}$ & $\begin{array}{l}\text { Detail inventory of individual } \\
\text { hotels, field verification }\end{array}$ \\
\hline 7 & $\begin{array}{l}\text { Dolakha, } \\
\text { Solukhumbu }\end{array}$ & $\begin{array}{l}\text { Everest region- Charikot, Jiri, } \\
\text { Bhandar-Junbesi-Salleri-Namche }\end{array}$ & $\begin{array}{l}\text { Detail inventory of individual } \\
\text { hotels, field verification }\end{array}$ \\
\hline 8 & Kavre & $\begin{array}{l}\text { Dhulikhel, Panauti, Namobuddha, } \\
\text { Balthali }\end{array}$ & $\begin{array}{l}\text { Detail inventory of individual } \\
\text { hotels, field verification }\end{array}$ \\
\hline 9 & $\begin{array}{l}\text { Bhaktapur, Kavre } \\
\text { Bhaktapur, Changunarayan and } \\
\text { Nagarkot }\end{array}$ & $\begin{array}{l}\text { Detail inventory of individual } \\
\text { hotels, field verification }\end{array}$ \\
\hline 10 & $\begin{array}{l}\text { Taplejung } \\
\text { Suketar, Phungling-Ghunsa trail }\end{array}$ & $\begin{array}{l}\text { Detail inventory of individual } \\
\text { hotels, field verification }\end{array}$ \\
\hline
\end{tabular}

Table 5: Major tourist sites covered during the accommodation enterprise survey, 2010 


\section{Scope of the Research Work}

The scope of the research findings lies under the considerations of the followings aspects:

Selection of tourist sites for the research work: These research findings cover the tourist accommodation enterprises available only in the selected 15 major and five minor tourist sites (Table 3 ) of the country.

1. Selection of tourist accommodation enterprises by its types: Accommodation enterprises in this research work refer only to all forms of tourist hotels, lodges, resorts, homestays etc. which primarily provide lodging and food facilities to the visitors. But this inventory report does not cover other forms of accommodation enterprises such as restaurants, bars etc. This inventory also does not cover any facilities and services for camping form of accommodation and other associated facilities and services such as parking facilities, conference facilities etc.

2. Categorization of tourist accommodation enterprises by their status of registration: Besides making the inventory of formal tourist accommodation enterprises which are registered at the Tourism Industry Division and respective tourism offices, following accommodation enterprises have also been covered in this research:

i. Accommodation enterprises registered only at the Department of Industry or the Cottage and Small Industry Development Board or its district offices and offering lodging and food services to the visitors.

ii. Accommodation enterprises permitted by and registered only at the respective protected area authorities such as national parks (PAs), wildlife reserves (WRs), hunting reserves (HRs) and conservation areas (CAs), and offering lodging and food services to the visitors.

iii. Accommodation enterprises registered only at the local government bodies like village development committees (VDCs) and municipalities and offering lodging and food services to the visitors.

iv. Accommodation enterprises registered only at the local community institutions like cooperatives, tourism committees etc. and offering lodging and food services to the visitors.

v. Accommodation enterprises which were actually offering services and facilities to the visitors in the trekking/tourism destinations but were not registered in any government institutions and local community institutions.

3. Classification of tourist accommodation enterprises: During the time of research (by June 2010), only four categories of tourist accommodation i.e. $\mathrm{TSH}$, lodges, resorts and star hotels prevailed in the country. The provision 
regarding the establishment of homestay enterprises only came into action in August 2010. However, this inventory report comprises the following additional categories of enterprises as tourist accommodation enterprises:

i. Tea house lodge: All unregistered lodges built and offering services for the visitors in the major trekking routes/destinations. For the purpose of this research, all tea house lodges have been listed under the broader category of lodge. The non-registration status of these tea house lodges separates them from the formal/registered lodges.

ii. Homestay: Any household offering accommodation facilities and services to the visitors as a paying guest and in a completely homely environment.

iii. Community/Monastery lodge: Any formal or informal enterprises which are offering accommodation facilities and services to the visitors in a collective manner and in a public platform like community building or monastery etc. with or without being registered at the government institutions.

Moreover, tourist rooms and beds have been further classified into the five different categories i.e. (i) Suits, (ii) Deluxe, (iii) Standard, (iv) Normal (Generally having no attached bathroom and toilet) and (v) Dormitory (Generally having more than four beds per room) based on the general practices and subjective judgment of the physical facilities available in the tourist rooms.

\section{Limitations of the Research Work}

The research findings are subjected to the following two major limitations:The primary data collected through the accommodation enterprises survey are primarily based on the word of mouth information provided by the enterprise owners, operators and associated staff combined with some very limited access to legal documents and physical observation. Neither have all operators showed their valid documents demonstrating the legal entity and accommodation capacity nor have they permitted the enumerators to inspect and count the rooms and tourist beds.

For two major sites i.e. Kathmandu and Lalitpur districts and the Annapurna region, the inventory outcomes are largely dependent on the secondary information. For Kathmandu and Lalitpur districts, the database was taken from the TID/MoTCA and field verification was made to incorporate new hotels/lodges and delete those which are already shut down. The inventory outcome for the Annapurna region totally relied on the database provided by the ACAP Regional Office, Pokhara, Unit Conservation Office, Jomsom and Unit Conservation Office, Ghandruk. Physical observation and accommodation enterprise survey was made in very few areas like Jomsom and Muktinath to verify the status of enterprises in the Annapurna region. 


\section{Data Analysis, Results and Discussion}

The collected primary and secondary data was segregated into 15 spatial areas (major tourist sites) and the total capacity of tourist accommodation enterprises along with their types/standards and registration status was then calculated by using very simple statistical tools under the following three sub-headings:

i. Capacity of tourist accommodation facilities and services in the major selected tourist sites.

ii. Status of tourist accommodation enterprises based on their types and standards

iii. Status of tourist accommodation enterprises based on their status of registration

While calculating the capacity of accommodation enterprises in the Annapurna region, the following two assumptions were made to calculate the total tourist room and tourist bed capacity in the region:

i. By taking into consideration the existing lower and upper limits of average tourist bed size per tea house lodge available at Lower Mustang (20.90 beds), Ghorepani (14.35 beds) and Ghandruk (12.80 beds); on an average, 16 tourist beds (8 rooms @ 2 beds) per tea house lodge was assumed to prevail throughout the Annapurna region.

ii. Likewise, in case of homestay, on an average, 2 tourist beds (1 room @ 2 beds) per homestay were assumed to prevail in the Annapurna region.

\section{Capacity of Tourist Accommodation Facilities and Services in the Major Selected Tourism Areas of Nepal:}

A total of 2,604 tourist accommodation enterprises, comprising all lodges, $\mathrm{TSH}$, resorts, star hotels, homestays and community lodges, were recorded in the selected 15 major tourist sites and five minor tourist areas of Nepal. These enterprises offer a total of 35,789 tourist rooms and 69,040 tourist beds a day for the visitors in the selected tourist sites. While comparing the outcomes of present research with the 2009 tourist statistics of Nepal, it simply figures 2.42 times more by tourist beds, 2.51 times more by tourist rooms and 3.54 times more by the number of enterprises than that of the hotel accommodation capacity maintained at TID/MoTCA as of December 2009.

Of the total selected areas, Kathmandu and Lalitpur districts comprise the largest number of tourist beds with 259 enterprises, 8,679 tourist rooms and 16,606 tourist beds. After Kathmandu and Lalitpur districts, Pokhara Valley comprises the second largest number of tourist beds with 254 enterprises, 7,213 tourist rooms and 11,577 tourist beds. Annapurna region comprises the third largest number of tourist beds with 821 tourist enterprises, 5,590 tourist rooms and 11,114 tourist beds (NTB/CEST Nepal, 2010). 


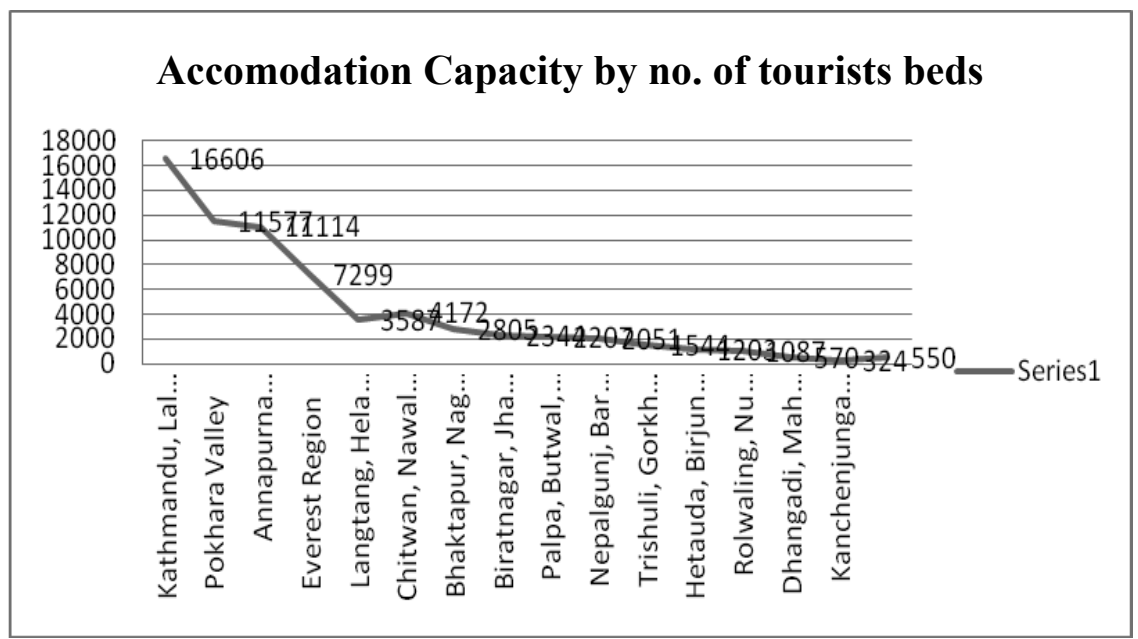

The Everest region comprises a total of 7,299 tourist beds followed by Chitwan and Nawalparasi (4,172 tourist beds); Langtang and Helambu region $(3,587$ tourist beds), Bhaktapur, Nagarkot and Dhulikhel (2,805 tourist beds), Biratnagar, Jhapa, Ilam, Dharan, Dhankuta (2,344 tourist beds), Palpa, Butwal, Bhairahawa and Lumbini (2,207 tourist beds), Nepalgunj, Bardiya and Surkhet (2,051 tourist beds), Trishuli, Gorkha, Manakamana, Bandipur, Lamjung (1,544 tourist beds), Hetauda, Birgunj and Janakpur (1,203 tourist beds), Rolwaling, Numbur, Sailung (1,087 tourist beds) and Dhangadhi and Mahendranagar ( 570 tourist beds). The Kanchenjunga region comprises the least number of tourist beds, having only 324 tourist beds, amongst the selected tourist areas (NTB/CEST Nepal, 2010).

By the number of accommodation enterprises, the Annapurna region comprises the largest number of enterprises (821 tourist enterprises) followed by the Everest region (313 tourist enterprises), Kathmandu and Lalitpur (259 tourist enterprises), Pokhara Valley (254 tourist enterprises), Langtang and Helambu region (221 tourist enterprises), Biratnagar, Jhapa, Ilam, Dharan, Dhankuta (146 tourist enterprises), Bhaktapur, Nagarkot and Dhulikhel (105 tourist enterprises), Chitwan and Nawalparasi (97 tourist enterprises), Trishuli, Gorkha, Bandipur, Lamjung (73 tourist enterprises), Rolwaling, Numbur and Sailung (72 tourist enterprises), Palpa, Butwal, Bhairahawa and Lumbini (52 tourist enterprises), Kanchenjunga region (31 tourist enterprises) and Hetauda, Birgunj, Janakpur (23 tourist enterprises). Dhangadhi and Mahendranagar comprise the least number of enterprises (17 tourist enterprises) amongst the selected tourist sites (Table-6).

Amongst the selected tourist sites, Kathmandu and Lalitpur districts score the highest figure for the average number of rooms per hotel (33.50 rooms per hotel) and average number of beds per hotel ( 64.11 beds per hotel). Kanchenjunga 
region scores the highest figure for the average number of beds per room ( 2.84 beds per room) amongst the selected tourist sites (NTB/CEST Nepal, 2010).

\begin{tabular}{|c|c|c|c|c|c|c|c|c|c|c|c|c|c|c|}
\hline \multirow{2}{*}{\begin{tabular}{|l|}
$S$ \\
$N$
\end{tabular}} & \multirow[t]{2}{*}{ Place } & \multirow{2}{*}{\begin{tabular}{|c|} 
Total \\
Hotels/ \\
Lodges
\end{tabular}} & \multicolumn{6}{|c|}{ Tourist Room } & \multicolumn{6}{|c|}{ Tourist Bed } \\
\hline & & & Suites & Deluxe & Standard & Normal & Dormitory & Total & Suites & Deluxe & Standard & Normal & Dormitory & Total \\
\hline 1 & \begin{tabular}{|l|} 
Kathmandu and \\
Lalitpur
\end{tabular} & 259 & 369 & 2,509 & 5,545 & 256 & & 8679 & 738 & 5,018 & 10,360 & 490 & & 16,606 \\
\hline 2 & \begin{tabular}{|l|} 
Bhaktapur, \\
Nagarkot, \\
Dhulikhel \\
\end{tabular} & 105 & 41 & 384 & 779 & 276 & 2 & 1,482 & 74 & 730 & 1,468 & 523 & 10 & 2,805 \\
\hline 3 & Pokhara Valley & 254 & 35 & 2,373 & 3,753 & 1,052 & & 7,213 & 71 & 3,928 & 5,949 & 1,629 & & 11,577 \\
\hline 4 & Annapurna Region & 821 & & & 1,834 & 3,756 & & 5,590 & & & 3,648 & 7,466 & & 11,114 \\
\hline 5 & Everest Region & 313 & 2 & 75 & 802 & 2,754 & 108 & 3,741 & 4 & 102 & 1,287 & 5,394 & 512 & 7,299 \\
\hline 6 & \begin{tabular}{|l} 
Rolwaling, \\
Numbur and \\
Sailung
\end{tabular} & 72 & 0 & 4 & 130 & 247 & 49 & 430 & 0 & 8 & 260 & 525 & 294 & 1,087 \\
\hline 7 & $\begin{array}{l}\text { Langtang and } \\
\text { Helambu Region }\end{array}$ & 221 & 0 & 0 & 76 & 1,333 & 94 & 1,503 & 0 & 0 & 164 & 2,967 & 456 & 3,587 \\
\hline 8 & \begin{tabular}{|l|} 
Chitwan and \\
Nawalparasi
\end{tabular} & 97 & 92 & 607 & 964 & 222 & 8 & 1,893 & 198 & 1,329 & 2,109 & 522 & 14 & 4,172 \\
\hline 9 & $\begin{array}{l}\text { Hetauda, Birgunj } \\
\text { and Janakpur }\end{array}$ & 23 & 40 & 184 & 282 & 88 & 6 & 600 & 87 & 396 & 521 & 167 & 32 & 1,203 \\
\hline 10 & $\begin{array}{l}\text { Biratnagar, Jhapa, } \\
\text { Ilam, Dharan, } \\
\text { Dhankuta }\end{array}$ & 146 & 12 & 216 & 366 & 612 & 18 & 1,224 & 18 & 379 & 670 & 1,199 & 78 & 2,344 \\
\hline 11 & \begin{tabular}{|l|} 
Kanchenjunga \\
Region
\end{tabular} & 31 & & & 25 & 89 & & 114 & & & 63 & 261 & & 324 \\
\hline 12 & \begin{tabular}{|l|} 
Trishuli, Gorkha, \\
Bandipur, \\
Besisahar \\
\end{tabular} & 73 & 40 & 44 & 299 & 402 & 1 & 786 & 77 & 82 & 531 & 850 & 4 & 1,544 \\
\hline 13 & $\begin{array}{l}\text { Palpa, Butwal, } \\
\text { Bhairahawa, } \\
\text { Lumbini }\end{array}$ & 52 & 17 & 202 & 502 & 117 & 83 & 921 & 31 & 369 & 949 & 269 & 589 & 2,207 \\
\hline 14 & $\begin{array}{l}\text { Nepalgunj, } \\
\text { Bardiya, Surkhet }\end{array}$ & 72 & 5 & 139 & 664 & 237 & 2 & 1,047 & 10 & 274 & 1,264 & 493 & 10 & 2,051 \\
\hline 15 & $\begin{array}{l}\text { Dhangadhi and } \\
\text { Mahendranagar }\end{array}$ & 17 & 23 & 88 & 131 & 49 & & 291 & 44 & 172 & 255 & 99 & & 570 \\
\hline 16 & \begin{tabular}{|l|}
$\begin{array}{l}\text { Miscellaneous } \\
\text { areas }\end{array}$ \\
\end{tabular} & & & & & & & & & & & & & \\
\hline$a$ & \begin{tabular}{|l|} 
Kodari Highway \\
(Sindhupalchowk)
\end{tabular} & 4 & & & 77 & & & 77 & & & 142 & & & 142 \\
\hline$b$ & Kakani/Nuwakot & 3 & & & 63 & & & 63 & & & 140 & & & 140 \\
\hline c & Daman & 1 & & 30 & & & & 30 & & 60 & & & & 60 \\
\hline$d$ & Khandbari & 3 & & & 46 & & & 46 & & & 79 & & & 79 \\
\hline $\mathrm{e}$ & Sirubari & 37 & & & & 59 & & 59 & & & & 129 & & 129 \\
\hline & Grand Total & 2604 & 676 & 6855 & 16338 & 11549 & 371 & 35789 & 1352 & 12847 & 29859 & \begin{tabular}{|l|}
22983 \\
\end{tabular} & 1999 & 69040 \\
\hline
\end{tabular}

Table 6: Summary of accommodation enterprises capacity in the major selected tourism areas of Nepal

Source: Accommodation research report/NTB/CEST Nepal, 2010

\section{Tourist Accommodation Enterprises by Standard and Types:}

Of the total 2,604 enterprises recorded in the major tourist sites, 106 enterprises (4.07\%) fall under the star hotel and 2,479 enterprises (95.92\%) fall under the non-star hotel category. Of the total star category hotels, Kathmandu and Lalitpur comprise 63 hotels, or about $59.45 \%$ of the total star hotels, followed 
by Pokhara Valley which comprises 18 star hotels (16.98\%). Of the total 2,604 accommodation enterprises, 64 are tourist resorts $(2.45 \%$ of the total and $2.58 \%$ of the non-star hotels), 385 are tourist standard hotels-TSH (14.78\% of the total and $15.53 \%$ of the non-star hotels), 1,716 are lodges ( $65.58 \%$ of total and $69.22 \%$ of non-star hotels), 297 are homestays (11.40\% of total and $11.98 \%$ of non-star hotels), and 16 are community/monastery lodges $(0.61 \%$ of total and $0.64 \%$ of non-star hotels) (Table 8), (NTB/CEST Nepal, 2010).

\section{Homestay Accommodation Services and Facilities:}

The inventory report also reveals that a total of 1,020 tourist beds are available at the 297 homestays developed in eight various rural villages of Nepal including Sirubari (Syangja), Gurung Heritage Trail (Ghalegaun-Pasgaun-Nagidhar), Barapak homestay (Gorkha), Tamang Heritage Trail (Rasuwa), Indigenous Peoples Trail (Ramechhap), Numbur Cheese Circuit (Ramechhap), Shree Antu (Ilam) and Olangchung Gola (Taplejung). Amongst the available homestay villages, Shree Antu, llam comprises the largest number of tourist beds (403 beds) whereas Olangchung Gola comprises the least number of homestay tourist beds ( 12 beds) (Table 7), (NTB/CEST Nepal, 2010).

\begin{tabular}{|l|l|l|l|l|l|}
\hline SN & District & \multicolumn{1}{|c|}{ Village Tourism Products } & $\begin{array}{r}\text { No. of } \\
\text { Homestays }\end{array}$ & $\begin{array}{c}\text { No. of } \\
\text { Rooms }\end{array}$ & $\begin{array}{c}\text { No. of } \\
\text { Beds }\end{array}$ \\
\hline 1 & Ilam & Shree Antu & 63 & 167 & 403 \\
\hline 2 & $\begin{array}{l}\text { L a m j u n g / } \\
\text { Kaski }\end{array}$ & Gurung Heritage Trail (Ghalegaun) & 124 & 124 & 248 \\
\hline 3 & Syangja & Sirubari village tourism & 37 & 59 & 126 \\
\hline 4 & Rasuwa & Tamang Heritage Trail (THT) & 27 & 39 & 99 \\
\hline 5 & Ramechhap & Numbur Cheese Circuit (NCC) & 11 & 20 & 52 \\
\hline 6 & Ramechhap & Indigenous Peoples Trail (IP Trail) & 11 & 18 & 40 \\
\hline 7 & Gorkha & Barapak village tourism & 20 & 20 & 40 \\
\hline 8 & Taplejung & Olangchung Gola cultural village & 4 & 4 & 12 \\
\hline Total & & & 297 & 451 & $\mathbf{1 , 0 2 0}$ \\
\hline
\end{tabular}

Table 7: Summary of homestay accommodation facilities in the major selected tourist sites

Source: Accommodation research report/NTB/CEST Nepal, 2010 


\begin{tabular}{|c|c|c|c|c|c|c|c|c|c|c|c|c|c|}
\hline \multirow{2}{*}{$\begin{array}{l}\mathrm{S} \\
\mathrm{N}\end{array}$} & \multirow{2}{*}{ Destinations/Hubs/Routes } & \multicolumn{6}{|c|}{ Star category } & \multicolumn{5}{|c|}{ Non-star Category } & \multirow{2}{*}{$\begin{array}{l}\text { Granc } \\
\text { Total }\end{array}$} \\
\hline & & $5 S$ & $4 S$ & $3 S$ & $2 S$ & is & Total & Resort & TSH & Lodge & Homestay & C/ML & \\
\hline 1 & Kathmandu and Lalitpur & 8 & 2 & 14 & 20 & 19 & 63 & 5 & 179 & 12 & & & 259 \\
\hline 2 & Bhaktapur, Nagarkot, Dhulikhel & 0 & 0 & 2 & 1 & 1 & 4 & 9 & 33 & 59 & 0 & 0 & 105 \\
\hline 3 & Pokhara Valley & 2 & & 4 & 11 & 1 & 18 & 7 & 77 & 152 & & & 254 \\
\hline 4 & Annapurna Region & & & & & & & & & 697 & 124 & & 821 \\
\hline 5 & Everest Region & 0 & 0 & 0 & 0 & 0 & 0 & 4 & 11 & 298 & 0 & 0 & 313 \\
\hline 6 & Rolwaling, Numbur and Sailung & 0 & 0 & 0 & 0 & 0 & 0 & 2 & 5 & 35 & 22 & 8 & 72 \\
\hline 7 & Langtang and Helambu Region & 0 & 0 & 0 & 0 & 0 & 0 & 0 & 0 & 193 & 27 & 1 & 221 \\
\hline 8 & Chitwan and Nawalparasi & 0 & 0 & 0 & 0 & 0 & 0 & 16 & 15 & 66 & 0 & 0 & 97 \\
\hline 9 & Hetauda, Birgunj and Janakpur & 0 & 0 & 1 & 4 & 3 & 8 & & 11 & 4 & & & 23 \\
\hline 10 & $\begin{array}{l}\text { Biratnagar, Jhapa, llam, Dharan, } \\
\text { Dhankuta }\end{array}$ & & & 1 & 1 & 1 & 3 & 4 & 20 & 56 & 63 & 0 & 146 \\
\hline 11 & Kanchenjunga Region & & & & & & & & 3 & 24 & 4 & & 31 \\
\hline 12 & Trishuli, Gorkha, Bandipur, Besisahar & 0 & 0 & 0 & 0 & 0 & 0 & 6 & 2 & 45 & 20 & 0 & 73 \\
\hline 13 & Palpa, Butwal, Bhairahawa, Lumbini & 0 & 0 & 1 & 1 & 2 & 4 & 0 & 16 & 25 & 0 & 7 & 52 \\
\hline 14 & $\begin{array}{l}\text { Nepalgunj, Gulariya, Thakurdwara, } \\
\text { Surkhet }\end{array}$ & 0 & 0 & 0 & 0 & 3 & 3 & 5 & 8 & 56 & & & 72 \\
\hline 15 & Dhangadhi and Mahendranagar & 0 & 0 & 1 & 0 & 1 & 2 & 5 & 10 & & & & 17 \\
\hline 16 & Miscellaneous areas & & & & & & & & & & & & \\
\hline a & Kodari Highway (Sindhupalchowk) & & & & & & & 3 & & 1 & & & 4 \\
\hline b & Kakani/Nuwakot & & & & & & & 3 & & & & & 3 \\
\hline c & Daman & & & 1 & & & 1 & & & & & & 1 \\
\hline$d$ & Khandbari & & & & & & & & & 3 & & & 3 \\
\hline $\mathrm{e}$ & Sirubari & & & & & & & & & & 37 & & 37 \\
\hline \multicolumn{2}{|c|}{ Grand Total } & 10 & 2 & 25 & 38 & 31 & 106 & 69 & 390 & 1,726 & 297 & 16 & 2,604 \\
\hline
\end{tabular}

Table 8: Summary of accommodation facilities and services by types and standards

Note: S-Star Hotels, C/ML-Community/Monastery Lodge

Source: Accommodation research report/NTB/CEST Nepal, 2010

Tourist Accommodation Enterprises by Status of Registration:

Out of the total 2,604 tourism accommodation enterprises recorded in the selected major tourism sites, only 637 enterprises $(24.46 \%)$ are registered as tourist accommodation enterprises at the Tourism Industry Division (TID) and the respective tourism offices in Kakadbhitta, Biratnagar, Birgunj, Pokhara, 
Bhairahawa and Nepalgunj under the Ministry of Tourism and Civil Aviation. Furthermore, 403 enterprises (15.47\%) are registered only at the respective Cottage and Small Industry Development Board/Committee and/or Department of Industry/District Industry Offices as formal accommodation enterprises. Likewise, 704 enterprises (27.03\%) are registered and/or recorded only at the respective protected areas (PAs). The largest volume under this category falls in the Annapurna Conservation Area (650 enterprises) with Langtang NP claiming the second largest volume with 47 enterprises. A total of 64 enterprises (2.45\%) are registered only at local municipalities and VDCs, while 759 enterprises (29.14\%) are registered nowhere (Table 9) (NTB/CEST Nepal, 2010).

Principally, all star hotels (106 enterprises), resorts (64 enterprises) and tourist class hotels (385 enterprises) are formally registered as tourist accommodation enterprises. Both formal (registered) and non-formal (non-registered) enterprises have been included in the lodge category $(1,716$ enterprises) for this inventory. All homestays (297 enterprises) and community/monastery lodges fall under the non-registered enterprises. Most of the formal accommodation enterprises are also affiliated with Hotel Association Nepal (HAN), Kathmandu and respective regional and district chapters. Almost all of them are also affiliated with the Federation of Nepalese Chambers of Commerce and Industries (FNCCI). Some accommodation enterprises which are registered at the respective protected areas (PAs), particularly in Chitwan NP and Sagarmatha NP, have also been registered at TID and tourism offices as formal tourist accommodation enterprises. Most of the homestays are registered at the local tourism management committees (Briddim, Sirubari, Indigenous Peoples Trail (IP Trail), Numbur Cheese Circuit (NCC), Shree Antu (Ilam) and some of them are registered at the local cooperatives (Rolwaling area) (NTB/CEST Nepal, 2010).

\begin{tabular}{|l|l|l|l|l|l|l|l|l|}
\hline SN & Destinations/Hubs & $\begin{array}{l}\text { Registered } \\
\text { at TID/ } \\
\text { TOS }\end{array}$ & $\begin{array}{l}\text { Registered } \\
\text { only at } \\
\text { Dol/CSIDB }\end{array}$ & $\begin{array}{l}\text { Registered } \\
\text { only at } \\
\text { PAs }\end{array}$ & $\begin{array}{l}\text { Registered } \\
\text { only at } \\
\text { municipality }\end{array}$ & $\begin{array}{l}\text { Registered } \\
\text { no where }\end{array}$ & Total & Remarks \\
\hline 1 & Kathmandu and Lalitpur & 259 & & 0 & & 0 & 259 & $\begin{array}{l}196 \text { affiliated with } \\
\text { HAN }\end{array}$ \\
\hline 2 & Bhaktapur, Nagarkot, Dhulikhel & 44 & 51 & 0 & 3 & 7 & 105 & \\
\hline 3 & Pokhara Valley & 150 & 54 & & 17 & 33 & 254 & \\
\hline 4 & Annapurna Region & 25 & 64 & 650 & & 82 & 821 & $\begin{array}{l}\text { Registered/recorded } \\
\text { at ACAP }\end{array}$ \\
\hline 5 & Everest Region & 13 & 15 & 0 & 0 & 285 & 313 & \\
\hline 6 & $\begin{array}{l}\text { Rolwaling, Numbur and } \\
\text { Sailung }\end{array}$ & 4 & 13 & 0 & 0 & 55 & 72 & 6 registered in \\
cooperatives, 22 \\
in HS
\end{tabular}




\begin{tabular}{|l|l|l|l|l|l|l|l|l|}
\hline 10 & $\begin{array}{l}\text { Biratnagar, Jhapa, llam, } \\
\text { Dharan, Dhankuta }\end{array}$ & 26 & 16 & 0 & 40 & 64 & 146 & $\begin{array}{l}63 \text { registered in } \\
\text { Homestay Com. }\end{array}$ \\
\hline 11 & Kanchenjunga Region & 3 & 5 & 0 & 0 & 23 & 31 & \\
\hline 12 & $\begin{array}{l}\text { Trishuli, Gorkha, Bandipur, } \\
\text { Besisahar }\end{array}$ & 10 & 19 & 0 & 1 & 43 & 73 & $\begin{array}{l}20 \text { registered in } \\
\text { Homestay Com. }\end{array}$ \\
\hline 13 & $\begin{array}{l}\text { Palpa, Butwal, Bhairahawa, } \\
\text { Lumbini }\end{array}$ & 20 & 25 & 7 & 0 & 0 & 52 & \\
\hline 14 & $\begin{array}{l}\text { Nepalgunj, Gulariya, } \\
\text { Thakurdwara, Surkhet }\end{array}$ & 16 & 56 & 0 & 0 & 0 & 72 & \\
\hline 15 & $\begin{array}{l}\text { Dhangadhi and } \\
\text { Mahendranagar }\end{array}$ & 6 & 8 & 0 & 3 & 0 & 17 & 1 also registered \\
in WR
\end{tabular}

Table 9: Summary of accommodation enterprises by status of registration

Abbreviated form (Table 9): TID: Tourism Industry Division, TOs: Tourism Offices, CSIDB: Cottage and Small Industry Development Board/Committee, DOI: Department of Industry, PA: Protected Areas, CNP: Chitwan National Park, ACAP: Annapurna Conservation Area Project, VDC: Village Development Committee, HAN: Hotel Association Nepal.

Source: Accommodation research report/NTB/CEST Nepal, 2010

\section{Conclusions}

1. The research finding has presented a generally expected but quite different scenario of tourist accommodation capacity, revealing the presence of more than two-and-half times more tourist bed capacity than that of formally registered tourist accommodation in the country. The study has also revealed the overwhelming number of enterprises coming up in tourist areas like the Pokhara Valley, Annapurna region, Everest region, Langtang region, Rolwaling-Sailung areas and upcoming tourist sites. The findings of the research can be a useful baseline data in the changed scenario for the policy makers, supervising agencies, entrepreneurs, development agencies and local communities in performing the following tourism tasks:

i. Setting expansion, upgrading and development strategy and action plan for accommodation infrastructure on a priority basis. 
ii. Undertaking capacity enhancement and quality upgrading activities in the major tourism areas

iii. Enhancing the effectiveness of tourism regulatory activities such as monitoring and supervision mechanism for ensuring the standard of accommodation services and facilities.

iv. Setting appropriate tourism forecasting and marketing strategies based on the accommodation facilities and services available in the major tourism areas

2. Out of the total tourist accommodation enterprises recorded in the inventory report, the vast majority of the accommodation enterprises fall under the non-star category. By considering the fact that most of the lodges, especially the tea house lodges, are non-registered, it can be interpreted that the accommodation facilities and services in the major tourist areas may be of inadequate qualities, in the absence of any controlling mechanism, demanding efforts for upgrading and improvements.

3. In the meantime, the huge presence of lodges, especially the tea house lodges, and the emerging trend of homestays and community lodges reflects that more rural and ecotourism-based accommodation enterprises are coming up in the country demanding efforts for strengthening and institutionalizing the new forms of accommodation enterprises.

4. Out of the tourist accommodation enterprises recorded by the inventory, less than a quarter of the total enterprises are formally registered at TID and tourism offices as tourism accommodation enterprises. Accommodation enterprises which are now registered only at the CSIDB/Dol can be considered as potential enterprise to be registered at TID. Furthermore, enterprises which are registered/ recorded only at the protected areas (PAs), particularly in the ACAP region, can be considered as most vulnerable in terms of legal aspects, revenue generation and controlling mechanism. Overall, there is a huge potential for tourism industry to upgrade and strengthen the larger number of formal and informal accommodation enterprises to be upgraded and registered as formal tourist accommodation enterprises.

5. The very poor number of accommodation enterprises registered at the TID could possibly be due to the lack of awareness about the tourism rules and regulations among the operators, poor enforcement of rules and regulations compounded by the poor supervision and monitoring mechanism and impractical administrative procedure of registration, particularly for the enterprises running in the remote trekking destinations. Throughout the whole inventory, no uniform and standard format was found being used by any government agencies for keeping and maintaining the records of registered accommodation enterprises. Moreover, there is a very poor and 
inadequate information sharing, partnership and collaboration mechanism among the CSIDB, municipalities, Nepal Tourism Board, TID/MoTCA and tourism offices for maintaining and sharing the database on tourism enterprises.

6. Altogether 2,604 accommodation enterprises, 35,789 tourist rooms and 69,040 tourist beds were recorded in the 15 major and five minor tourism sites of Nepal. However, findings of this inventory largely exclude the enterprise database on other new and upcoming tourist sites, database on the other services and facilities such as conference facilities etc. associated with the hotel/lodge enterprises and the quality aspects of the accommodation enterprises.

\section{Recommendations}

1. Tourist Industry Division/Ministry of Tourism and Civil Aviation and Nepal Tourism Board (NTB) together with Hotel Association Nepal (HAN) should develop a standard and uniform format for maintaining the records of tourist accommodation enterprises throughout the country. NTB and TID should enhance and strengthen the capacity of protected areas authority, CSIDB/Dol, VDCs, municipalities and other local tourism committees by providing orientation training and appropriate software package etc. for ensuring updated database keeping, management and sharing system on tourism accommodation enterprises.

2. TID/MoTCA together with NTB and HAN should prepare a comprehensive tourist accommodation inventory on a periodic basis by also incorporating the following missing attributes of tourist accommodation enterprises:

i. The new inventory research should cover other accommodationrelated enterprises such as restaurants, bars, camping sites, safari tents etc.

ii. The new inventory research should also cover other associated facilities and services such as parking facilities, conference facilities and other entertainment facilities available in the hotels/lodges/resorts.

iii. The new inventory research should also cover the facilities available at other new, upcoming and promising tourist destinations such as HileBasantapur-Gufapokhari, Makalu-Barun area, Helambu-PanchpokhariChautara route, Manaslu region, Dhorpatan and Lower Dolpo region, Jumla and Simikot region, Khaptad areas and all upcoming Terai areas.

3. Special campaign should be initiated to bring all potential tourist accommodation enterprises under the jurisdiction of TID/MoTCA by encouraging and helping them to register their enterprises in the prescribed 
agencies. TID/MoTCA and Nepal Tourism Board in association with Trekking Agencies Association of Nepal (TAAN) should develop a separate policy and operating procedure to register, operate and regulate following tourist accommodation enterprises under the special categories:

i. Tea house lodges (in the major trekking trails)

ii. Homestays (already covered in the Home-stay Operating Procedure, August 2010)

iii. Community-managed public accommodation enterprises (Monastery lodges, community lodges/guesthouses, cooperative lodges, Dharmashala, community camping sites etc.)

4. TID/MoTCA, Nepal Academy of Tourism and Hotel Management (NATHM) and NTB together with HAN should initiate tourist accommodation enterprise upgrading and strengthening program, particularly in the trekking destinations and upcoming new areas. Special emphasis should be given to the physical facilities of the tourist hotels (room, bed, toilet, lighting, space etc.), hygiene and sanitation conditions, and quality of food offered to the visitors.

\section{References}

GoN, 1998, Gazette published by the Government of Nepal dated Ashwin 4, 2055 regarding the setting up of criteria for the classification of resorts and star hotels, Ministry of Tourism and Civil Aviation, Kathmandu Nepal.

Eco-Himal (2007), Experience Eco-Lodge Trekking in the Unspoilt Gauri Shankar Area (a promotional brochure), Eco-Himal, Kathmandu Nepal.

HMG/N, 1996, Conservation Area Management Regulations 1996 (2053 BS), Kathmandu Nepal.

HMG/N, 2000, Conservation Area Government Management Regulations 2000 (2057 BS), Kathmandu, Nepal.

HMG/N, 1996, Buffer Zone Management Regulation 1996 (2052 BS), Kathmandu, Nepal.

HMG/N, 1999, Buffer Zone Management Directive 1999 (2056 BS), Kathmandu, Nepal.

HMG/N, 1973, National Parks and Wildlife Conservation Act 1973 (4th amendment, 1993), Kathmandu, Nepal.

HMG/N, 1978, Tourism Act 2035 (3rd amendment, 1997), Kathmandu, Nepal.

HAN, 2008, Hotel Directory 2008, Hotel Association Nepal, Gairigaun, Kathmandu, Nepal

Kanel, CN, 2010, Homestay Management in Nepal: Some practical Aspects, Treasures of Dolakha, Dolakha Tourism Development Committee, Dolakha, Nepal. 
MoTCA (2006), Tourism Policy 2065 (2008), Ministry of Tourism and Civil Aviation (MoTCA), Kathmandu, Nepal.

MoTCA (2009), Nepal Tourism Statistics 2009, Ministry of Tourism and Civil Aviation, Kathmandu, Nepal

NTB/CEST Nepal (2010), An Inventory of formal accommodation facilities in the major selected tourist areas of Nepal, Nepal Tourism Board and Centre for Environment and Sustainable Tourism Development Nepal, Kathmandu, Nepal.

NTB/CEST Nepal (2008), Tourism Development and Management Plan of Manakamana, Betini and Bakreshwori, Gorkha, (2008/09 to 2012/013), Nepal Tourism Board and Centre for Environment and Sustainable Tourism Development Nepal, Kathmandu, Nepal.

Satyal Y.R. (2004), Tourism in Nepal: A Profile. India: Adroit Publication.

Sedai, R.C. (2010), Tourism Value Chain Upgrading in Ramechhap: Task completion report, International Labor Organization/Employment Creation and Peace Building Based on Local Economic Development (ILO/EmPLED), Kathmandu, Nepal.

TID/MoTCA, 2007, Internal Operating Regulation 2064 published by Tourism Industry Division/Ministry of Tourism and Civil Aviation, Bhrikutimandap, Kathmandu Nepal.

TID/MoTCA, 2008, Registered Tourism Related Enterprises 2008, Tourism Industry Division/Ministry of Tourism and Civil Aviation, Bhrikutimandap, Kathmandu, Nepal.

UNWTO (2008), International Recommendations for Tourism Statistics, United Nations World Tourism Organization, Madrid, New York. 